ks. Leszek Mateja ${ }^{1}$

0000-0003-0326-6552

Uniwersytet Papieski Jana Pawła II w Krakowie

\title{
Chrzest jako misterium pieczęci w tradycji pierwszych trzech wieków
}

W praktyce duszpasterskiej współczesnego Kościoła obserwuje się tendencję do zaakcentowania samego chrztu jako środka do zbawienia, często bagatelizując prawdę, że owocność chrztu jest związana z koniecznością posiadania wiary, co podkreśla zakończenie Ewangelii według św. Marka: „Kto uwierzy i przyjmie chrzest będzie zbawiony” (Mk $16,16)^{2}$. Nawet jeśli dziś mówi się o konieczności posiadania wiary przez ochrzczonego, to często sprowadza sięją tylko do wymiaru intelektualnego. Natomiast doświadczenie wypływające z tradycji starożytnego Kościoła podkreśla konieczność posiadania egzystencjalnej wiary, wyrażonej w praktyce życia i weryfikowanej w procesie inicjacji przedchrzcielnej ${ }^{3}$.

1 Ks. dr Leszek Mateja - absolwent patrologii na Wydziale Teologicznym PAT w Krakowie, proboszcz parafii pw. Narodzenia Najświętszej Maryi Panny w Rusocicach w archidiecezji krakowskiej. E-mail: leszekmateja@poczta.onet.pl.

2 Por. B. Górka, Struktura inicjacji w tzw. dłuższym zakończeniu Ewangelii Marka (16,9-20), w: B. Górka, Kerygma i Ekklesia w kontekście inicjacji, Kraków 2016, s. 13-32.

3 Zob. L. D. Folkemer, A study of the Catechumenate, "Church History” 15 (1946), s. 286- 307; B. Mokrzycki, Droga chrześcijańskiego wtajemniczenia, Warszawa 1983, s. 38- 105; M. E. Johnson, The Rites od Christian Initiation. Their Evolution and Interpretation, Collegeville 2007, s. 84-90; E. Ferguson, Baptism in the Early Church. History, Theology, and Liturgy in the First Five Centuries, Grand Rapids 2009, s. 336-345; Katechumenat i inicjacja chrześcijańska w Kościele 
Tak rozumiana wiara była wtedy nieodłącznym elementem przygotowania do chrztu. Pragnąc pokrótce przypomnieć tę tradycję z pierwszych trzech wieków, przedstawimy najpierw sens chrztu Janowego, a następnie istotę chrztu chrześcijan, która została wyrażona w symbolice pieczęci chrztu przez pisarzy chrześcijańskich żyjących w II i III wieku: autora Pasterza Hermasa, Klemensa Aleksandryjskiego i Tertuliana.

\section{Chrzest Jana Chrzciciela jako pieczęć nawrócenia}

Tradycja chrztu przyjmowanego przez chrześcijan wyrasta z wcześniejszego doświadczenia obmyć rytualnych, a zwłaszcza chrztu udzielanego przez Jana Chrzciciela. Dlatego pragnąc ukazać istotę chrztu chrześcijan w tradycji pierwszych trzech wieków, pokrótce spojrzymy na chrzest Janowy na podstawie Ewangelii Marka, uważanej za najstarsze nowotestamentalne świadectwo dotyczące interesującego nas tematu. Święty Marek po ukazaniu przesłania Dobrej Nowiny, którąjest tajemnica Jezusa jako Mesjasza i Syna Bożego (Mk 1, 1), umiejscawia ją w kontekście zbawczej inicjatywy Boga, cytując słowa ze Starego Testamentu (Mk 1, 2-3), które są kompilacją dwóch jego fragmentów: Ml 3, 1 i Iz 40, 3. Ewangelista przypisuje je Izajaszowi, dlatego, że Księga Izajasza rozpoczynała zwój ksiąg prorockich i od nazwy pierwszej księgi zwyczajowo określano tym mianem cały ten zwój. Wysłannik Boga, o którym jest mowa w Mk 1, 2b jest posłany, aby przygotować drogę Jezusa. W kolejnym wersecie przez cytat Iz 40, 3 ewangelista przechodzi z czasu zapowiedzi do czasu realizacji. Przygotowanie drogi dla Jezusa staje się teraz konkretnym apelem Bożego wysłannika, skierowanym do słuchaczy jego orędzia. Werset czwarty odsłania imię zapowiadanego przez proroków Bożego zwiastuna, którym jest Jan Chrzciciel. Wystąpił on na pustkowiu i „głosił chrzest nawrócenia na odpuszczenie grzechów” (Mk 1,4)4.

starożytnym, red. F. Drączkowski, J. Pałucki, P. Szczur, M. Szram, M. Wysocki, M. Ziółkowska, Lublin 2011.

4 Por. S. Haręzga, Jezus i Jego uczniowie. Model chrześcijańskiej formacji w Ewangelii według św. Marka, Lublin 2006, s. 41. 
Do Jana Chrzciciela przychodziła tylko ludność z Judei i z samej Jerozolimy (Mk 1, 5), dlatego też Jezus po uwięzieniu Jana kontynuuje jego misję na terenie Galilei (Mk 1, 14-15). Mając na uwadze składnię wersetu piątego, gdzie zwrot „wyznając swe grzechy” jest podporządkowany drugiemu orzeczeniu: „byli chrzczeni”, można stwierdzić, że wyznanie grzechów towarzyszyło aktowi chrztu w Jordanie. Nie był to zatem akt odseparowany od chrztu, ale czynność włączona w samo przyjmowanie chrztu. Ponadto nie ma żadnej wzmianki o odpuszczeniu grzechów, dlatego można wyciągnąć wniosek, że adresaci chrztu Jana byli wezwani do oczekiwania na przyjście Mesjasza, który dopiero miał odpuszczać grzechy. Jan podkreśla, że wobec Mesjasza nie może postawić się nawet w pozycji niewolnika, którego zadaniem było zdejmowanie sandała i obmycie stopy swego pana (Mk 1, 7). Następująca później zapowiedź chrztu, którego dokona Mesjasz w Duchu Świętym jest obietnicą usunięcia grzechów wyznawanych w czasie chrztu w Jordanie (Mk 1, 8) 5 .

Podsumowując tę krótką egzegezę Markowego opisu chrztu Janowego, należy stwierdzić, że chrzest ten nie odpuszczał grzechów, a jedynie przygotowywał do przyjęcia chrztu w imię Jezusa Chrystusa, który dawał tę łaskę. Pod koniec II wieku podkreślał tę prawdę Tertulian, kiedy pisał o chrzcie Jana Chrzciciela:

„Przepowiadał chrzest pokuty na odpuszczenie grzechów”, chodziło o przyszłe odpuszczenie grzechów. Na tym właśnie polega przygotowanie drogi. Kto zaś coś przygotowuje, nie sam dokonuje dzieła, lecz innym stwarza warunki do wykonania. Sam zresztą wyznaje, że jego chrzest nie jest z nieba, lecz Chrystusa ${ }^{6}$.

Tak więc autor interpretuje słowa Izajasza, jako przygotowanie drogi dla przyszłego doświadczenia odpuszczenia grzechów przez Chrystusa.

Starszym świadectwem, bo pochodzącym z I wieku, które rzuca światło na zrozumienie istoty chrztu Janowego są słowa Józefa Flawiusza o Janie Chrzcicielu:

5 Por. A. Malina, Ewangelia według św. Marka (1, 1-8, 26), cz. 1, Częstochowa 2013, s. 80.

6 Tertullianus, De baptismo, 10, 6-7, Paris 1952, s. 81 (Sources Chrétiennes, 35), przekł. pol.: Tertulian, O chrzcie, w: Tertulian, Wybór pism, tłum. E. Stanula, Warszawa 1970, s. 144 (Pisma Starochrześcijańskich Pisarzy, 5). 
Ów Jan, którego kazał zabić Herod, był zacnym mężem, zachęcał Judejczyków, by kształcili w sobie cnotę i by do chrztu przystępowali zachowując sprawiedliwość w stosunkach wzajemnych i gorliwie czcząc Boga. Miły Bogu będzie taki chrzest, głosił, jeśli potraktują go nie jako przebłaganie za jakieś występki, ale jako oczyszczenie ciała, duszę już przedtem dogłębnie oczyściwszy sprawiedliwością7 .

Przytoczone świadectwo ukazuje jak rozumiano w nieodległym czasie od śmierci Jana Chrzciciela istotę jego chrztu, gdzie akcent był położony przede wszystkim na przygotowanie wewnętrzne do tego wydarzenia. Zdaniem Józefa Flawiusza chrzest Janowy uświęcał ciało tych, którzy wcześniej oczyścili swą duszę.

Potwierdzeniem konieczności zmiany życia przed przyjęciem tego chrztu, są słowa samego Jana Chrzciciela, cytowane przez ewangelistę Łukasza: „Mówił więc do tłumów, które wychodziły, żeby przyjąć chrzest od niego (...) Wydajcie więc owoce godne nawrócenia" (Łk 3, 7-8). Jan wzywał do nawrócenia i potwierdzenia zmiany życia przez konkretne czyny, przed udzieleniem chrztu, a nie po nim. Chrzest w Jordanie miał bowiem wieńczyć proces nawrócenia, czyli spełniał funkcję pieczęci potwierdzającej nawrócenie człowieka. Ewangelista Łukasz cytuje również konkretne pytania różnych grup społecznych, które były kierowane do Jana Chrzciciela: „Cóż więc mamy czynić?” (Łk 3, 10). Z odpowiedzi, jakiej udzieliłJan zadającym mu pytania (por. Łk 3, 11-14) wynika, że istotą przygotowania do przyjęcia tego chrztu była postawa sprawiedliwości i miłosierdzia.

Innym świadectwem z I wieku, wywodzącym się ze środowiska żydowskiego, a dotyczącym obrzędu obmyć rytualnych, są pisma wspólnoty z Qumran. Członkowie tej wspólnoty uważali, że przyczyną utraty czystości rytualnej jest przekroczenie Bożych przykazań i dopiero po nawróceniu można było uczestniczyć w obrzędach oczyszczenia:

7 Józef Flawiusz, Dawne dzieje Izraela, 18, 117, tłum. Z. Kubiak, J. Radożycki, Warszawa 1979 , s. 846. 
Nie powinien wchodzić do wody, dotykając czystości ludzi świętych. Nie staną się bowiem czyści, dopóki nie odwrócą się od swego zła. Nieczystość jest bowiem we wszystkich tych, którzy przekraczają Jego przykazanie ${ }^{8}$.

Słowa te wyraźnie akcentują konieczność przemiany życia przed przystąpieniem do obrzędu oczyszczenia. Artur Malina komentując ten fragment, pisze:

Obmycie dawało czystość rytualną, zaś czystość moralna była warunkiem dopuszczenia do obrzędu. Poddanie się temu oczyszczeniu oznaczało, że już wcześniej miało miejsce nawrócenie. Uprzednie odbycie pokuty było bowiem warunkiem przystąpienia do wspólnoty i umożliwiało uczestnictwo w obrzędach, które od każdego i za każdym razem wymagały poddawania się obmyciu wodą. Innymi słowy, było to raczej obmycie ludzi już uświęconych niż dążących do uświęcenia9.

Przytoczone dwa świadectwa ze środowiska żydowskiego I wieku, jednoznacznie ukazują, że chrzest Janowy był udzielany tylko tym, którzy odwrócili się od zła i wrócili do Boga, potwierdzając to konkretnymi uczynkami sprawiedliwości i miłosierdzia. Chrzest Janowy spełniał rolę pieczęci potwierdzającej nawrócenie człowieka i przygotowywał go do doświadczenia odpuszczenia grzechów, jakiego miał udzielić Mesjasz we chrzcie w Duchu Świętym. Przygotowanie to polegało na uświadomieniu sobie grzechów przez człowieka i wyznaniu ich, bo tylko wtedy mógł je odpuścić Mesjasz.

\section{Pieczęć chrztu w Pasterzu Hermasa i w Kobiercach}

Pragnąc ukazać istotę chrztu udzielanego w starożytnym Kościele, przywołamy najpierw jedno z najstarszych świadectw dotyczących tego tematu. Jest nim fragment dzieła pt. Pasterz Hermasa, które powstało najprawdopodobniej między 140 a 150 rokiem w środowisku Kościoła Rzymskiego:

8 Rękopisy znad Morza Martwego. Qumran-Wadi Murabba'at-Masada, 1QS 5, 13-14, tłum. P. Muchowski, Kraków 1996, s. 28.

9 A. Malina, Ewangelia według św. Marka, dz. cyt., s. 71. 
Otrzymali zatem i ci pieczęć Syna Bożego i weszli do Bożego Królestwa. Dopóki człowiek bowiem nie nosi Imienia Syna Bożego, dopóty jest martwy. Kiedy zaś otrzyma pieczęć, odrzuca śmierć i przyjmuje życie. A pieczęcią tą jest woda. Do wody zatem wchodzą martwi, a wychodzą z niej żywi. Im również oznajmiono o pieczęci i posłużyli się nią, aby wejść do Królestwa Bożego ${ }^{10}$.

Autor nazywa chrzest pieczęcią Syna Bożego, co w wymiarze inicjacyjnym należy wiązać z egzystencjalnym wyznaniem wiary w Jezusa jako Syna Bożego, czyli Boga. Dzięki temu inicjowany doświadczał łaski ożywienia duchowego i mógł wejść do Królestwa Bożego, wcześniej bowiem w wymiarze duchowym pozostawał martwy.

Bardziej precyzyjnie proces ożywienia duchowego przedstawia inny autor, żyjący na przełomie II i III wieku, jakim jest Klemens z Aleksandrii, który w swym dziele Kobierce pisze w następujący sposób:

W możliwości każdego człowieka pozostaje nie być „synem buntu”, lecz przestąpić z ciemności do życia i nadstawiwszy ucha na mądrość, najpierw być niewolnikiem Boga zgodnie z Prawem, następnie stać się Jego wiernym sługą, który odczuwa obawę przed Bogiem, swym Panem; a jeśli ktoś jeszcze wyżej wstąpi, to możliwe, że zostanie powołany między synów Bożych. A gdy „miłość przysłoni całą mnogość grzechów”, to może on uzyskać pełnię szczęśliwej nadziei, urósłszy przez miłość i zaliczony w poczet wybranych do synostwa Bożego, a nawet nazywanych Jego przyjaciółmi - zaśpiewa modlitwę i powie: „Mój Pan winien stać się Bogiem moim"11.

Autor ukazuje możliwość wyjścia z ciemności i wejścia do życia dla tych, którzy byli zaliczani do „synów buntu”, a także perspektywę ich dalszego rozwoju duchowego od statusu „niewolników Boga”, do stania się „synami Bożymi”. Ten wzrost duchowy w starożytnym Kościele dokonywał się w trakcie procesu inicjacji przedchrzcielnej począwszy od prekatechumenatu, co Klemens nazywa etapem bycia „niewolnikiem

10 Hermas, Pastor, 93, 3- 4, Paris 1968, s. 326- 328 (Sources Chrétiennes, 53), przekł. pol.: Hermas, Pasterz, w: Pierwsi świadkowie. Pisma Ojców Apostolskich, wyd. 2, tłum A. Świderkówna, Kraków 1998, s. 280 (Biblioteka Ojców Kościoła, 10).

11 Clemens Alexandrinus, Stromata, 1, 26, 173, 6, Paris 1951, s. 170-171 (Sources Chrétiennes, 30), przekł. pol.: Klemens Aleksandryjski, Kobierce zapisków filozoficznych dotyczących prawdziwej wiedzy, t. 1, tłum. J. Niemirska-Pliszczyńska, Warszawa 1994, s. 119-120. 
Boga”, poprzez katechumenat, czyli bycie „wiernym sługą”, aż do przyjęcia chrztu, kiedy to inicjowany zostaje „powołany między synów Bożych". Autor podkreśla, że przyjęcie chrztu nie dokonuje się z automatu, lecz jest taka możliwość, o ile w życiu katechumena „miłość przysłoni całą mnogość grzechów” (1 P 4, 8), czyli jeśli zainteresowany urośnie duchowo przez miłość. Wtedy dopiero będzie mógł być „zaliczony w poczet wybranych do synostwa Bożego", bowiem w wymiarze egzystencjalnym będzie wtedy zdolny do wyznania wiary w bóstwo Jezusa, co autor wyraża za pomocą wyznania Jakuba: „Mój Pan winien stać się Bogiem moim” $(\operatorname{Rdz} 28,21)^{12}$.

Również Klemens, podobnie jak autor Pasterza Hermasa, używa symboliki pieczęci do wyrażenia tajemnicy chrztu, kiedy w tym samym dziele komentuje fragment z Księgi Rodzaju ( $R d z$ 22, 3-4):

„Abraham więc wyruszył do tego miejsca, które mu wymienił Bóg, a kiedy dnia trzeciego rozejrzał się znowu, ujrzał z daleka to miejsce”. Pierwszy oto dzień to dzień poświęcony oglądowi fizycznemu rzeczy pięknych. Drugi wypełnia pożądanie duszy w stosunku do rzeczy najlepszych, w trzecim rozum dochodzi do rozeznania rzeczy duchowych, gdy oczy umysłu zostały otwarte przez Nauczyciela zmartwychwstałego w trzecim dniu. Te trzy dni mogą też być symbolem misterium pieczęci, za pośrednictwem której doznaje umocnienia wiara w prawdzie istniejącego Boga ${ }^{13}$.

Aleksandryjczyk najpierw interpretuje symbolikę trzech dni w kluczu filozoficznym, kiedy Abraham zmierzał do kraju Moria, co podkreśla dalej w słowach: „Nieuchwytna jest bowiem kraina Boga, którą Platon nazywa krainą idei" ${ }^{14}$. Następnie zaznacza, że symbolikę tych trzech dni można odczytać w kluczu inicjacyjnym, jako przygotowanie

12 Por. S. Łucarz, Inicjacja w ujęciu Klemensa Aleksandryjskiego, w: Kondycja chrześcijaństwa dzisiaj a inicjacja chrześcijaństwa starożytności, Gdańsk 2005, s. 110-113 (Christianitas Antiqua. Commentationes, 1).

13 Clemens Alexandrinus, Stromata, 5, 11, 73, 1-2, Paris 1980, s. 146 (Sources Chrétiennes, 278), przekł. pol.: Klemens Aleksandryjski, Kobierce zapisków filozoficznych dotyczacych prawdziwej wiedzy, t. 2, tłum. J. Niemirska-Pliszczyńska, Warszawa 1994, s. 59-60.

14 Clemens Alexandrinus, Stromata, 5, 11, 73, 3, dz. cyt., s. 146 (Sources Chrétiennes, 278), przekł. pol.: Klemens Aleksandryjski, Kobierce zapisków filozoficznych dotyczących prawdziwej wiedzy, t. 2, tłum. J. Niemirska-Pliszczyńska, dz. cyt., s. 60. 
do chrztu, który nazywa misterium pieczęci. Klemens uważa, że tak rozumiany chrzest umacnia wiarę inicjowanego w prawdzie istniejącego Boga, co należy odnieść do poprzednio analizowanego fragmentu Kobierców, kiedy w podobny sposób mówił o wierze w bóstwo Jezusa. Tak więc autor kolejny raz podkreśla prawdę o konieczności posiadania egzystencjalnej wiary w Jezusa jako Syna Bożego, aby doświadczyć misterium pieczęci, czyli chrztu. Tym razem podkreślając wartość chrztu w kontekście umocnienia takiej wiary.

Klemens Aleksandryjski używa sformułowania misterium pieczęci w nawiązaniu do misteriów Greków, kiedy pisze:

Wobec tego nie bez słuszności misteria u Helenów zaczynają się od ofiar oczyszczalnych, jak u innych ludów od kąpieli. Po tych ofiarach następują misteria małe, których zadaniem jest dać podstawowe pouczenie i przygotowanie do tego, co ma nastąpić. Misteria zaś wielkie wprowadzają w to wszystko, co już nie pozostaje przedmiotem nauki, lecz oglądu bezpośredniego i uchwycenia rozumem natury rzeczywistości ${ }^{15}$.

Do tej pogańskiej tradycji autor odnosi doświadczenie chrześcijan pisząc:

Stopień oczyszczenia uzyskać możemy już przez wyznanie grzechów, ale stopień oglądu bezpośredniego - dopiero w wyniku analizy, dochodząc aż do pierwszego pojęcia ${ }^{16}$.

Autor sygnalizuje, że misterium małe w doświadczeniu chrześcijan związane byłoby z wyznawaniem grzechów, co w tradycji starożytnego Kościoła było nazywane eksomogoleza (exomologesis), która rozpoczynała katechumenat ${ }^{17}$. W kontekście inicjacyjnego odczytania Ewangelii misterium małe byłoby czasem rozwoju egzystencjalnej wiary w Jezusa

\footnotetext{
15 Clemens Alexandrinus, Stromata, 5, 11, 71, 1-2, dz. cyt., s. 142 (Sources Chrétiennes, 278), przekł. pol.: Klemens Aleksandryjski, Kobierce zapisków filozoficznych dotyczacych prawdziwej wiedzy, t. 2, tłum. J. Niemirska-Pliszczyńska, t. 2, s. 58.

16 Clemens Alexandrinus, Stromata, 5, 11, 71, 2, dz. cyt., s. 142 (Sources Chrétiennes, 278), przekł. pol.: Klemens Aleksandryjski, Kobierce zapisków filozoficznych dotyczących prawdziwej wiedzy, t. 2, tłum. J. Niemirska-Pliszczyńska, t. 2, s. 58.

17 Tertullianus, De paenitentia, 9, 1-2, Paris 1984, s. 180 (Sources Chrétiennes, 316), przekł. pol.: Tertulian, o pokucie, w: Tertulian, Wybór pism, tłum. E. Stanula, Warszawa 1970, s. 188 (Pisma Starochrześcijańskich Pisarzy, 5), por. L. Mateja, Wtajemniczenie w bezgrzeszność w „De paenitentia” Tertuliana, w: „Christianitas Antiqua” 7 (2015), s. 47.
} 
jako Mesjasza (Mk 8, 29). Natomiast misterium wielkie stanowiłoby drugi etap wtajemniczenia w Jezusa jako Syna Bożego (Mk 15, 39), zakończone otrzymaniem misterium pieczęci, czyli chrztu. Tę dwuetapowość wtajemniczenia Klemens ukazuje jeszcze w innym fragmencie kiedy pisze: wtedy dopiero przejdziemy do omówienia wyniku badań w zakresie prawdziwej wiedzy o bycie, uzyskawszy wtajemniczenie najpierw mniejsze przed wielkim ${ }^{18}$.

Podsumowując, należy stwierdzić, że zarówno autor Pasterza Hermasa reprezentujący środowisko Kościoła Rzymskiego, jak i Klemens, który jest przedstawicielem Kościoła Aleksandryjskiego, używają symboliki pieczęci do wyrażenia tajemnicy chrztu. W ich rozumieniu chrzest chrześcijan pieczętował egzystencjalne wyznanie wiary w Jezusa jako Syna Bożego, czyli Boga, jednocześnie wzmacniając tę wiarę. Ponadto Klemens precyzyjnie ukazuje proces wzrostu duchowego, aż do osiągnięcia pełnej dojrzałości syna Bożego, która była konieczna do przyjęcia chrztu.

\section{Pieczęć chrztu w pismach Tertuliana}

Kolejnym autorem chrześcijańskim, który używał symboliki pieczęci w kontekście chrztu, jest Tertulian żyjący na przełomie II i III wieku i reprezentujący środowisko Kościoła Kartagińskiego. W swym dziele O pokucie pisał:

Chrzest jest pieczęcią wiary. Wiara zaś rozpoczyna się i powierza się solidnej pokucie. Nie dlatego przyjmujemy chrzest, abyśmy przestali grzeszyć, lecz dlatego, że już nie grzeszymy, że już posiadamy serce czyste. To jest pierwszy chrzest katechumenów ${ }^{19}$.

18 Clemens Alexandrinus, Stromata, 4,1,3,1, s. 58 (Sources Chrétiennes 30), tłum. J. Niemirska-Pliszczyńska, t. 1, s. 298; por. S. Łucarz, Disciplina arcani w Kobiercach Klemensa Aleksandryjskiego, w: Disciplina arcani w chrześcijaństwie, red. W. Gajewski, B. Górka, Kraków 2015, s. 81-82.

19 Tertullianus, De paenitentia, 6.16-17, s. 168 (Sources Chrétiennes 316), tłum. E. Stanula, s. 184 (Pisma Starochrześcijańskich Pisarzy 5). 
Autor pisząc te słowa, polemizuje z tymi, którzy pragnęli zmienić dotychczasową procedurę wtajemniczenia w chrzest. Zdaniem Kartagińczyka chrzest pieczętuje wcześniejsze doświadczenie wiary, które było weryfikowane w trakcie procesu inicjacji nazywaną przez niego pokutą. Można sądzić, że Tertulian nawiązuje tu do symboliki pieczęci, którą stosuje św.Paweł, gdy pisze o obrzezaniu Abrahama: „otrzymał znak obrzezania jako pieczęć usprawiedliwienia osiągniętego dzięki wierze, którą miał wtedy, gdy jeszcze nie był obrzezany" (Rz 4,11). Obrzezanie Abrahama było więc aktem przypieczętowującym jego wcześniejsze doświadczenie usprawiedliwienia przez wiarę. Poprzez analogię można sądzić, że chrzest jest pieczęcią dla tych, którzy poprzez pokutę, będącą wyrazem ich wiary, doświadczyli również usprawiedliwienia przez wiarę. Dlatego Kartagińczyk podkreśla, że przystępujący do chrztu już nie grzeszy, bo jest usprawiedliwiony przez wiarę i to doświadczenie nazywa pierwszym chrztem katechumenów. Zmiana postępowania inicjowanego była owocem doświadczenia usprawiedliwienia, dzięki zjednoczeniu się przez wiarę z Jezusem Mesjaszem. To doświadczenie było przypieczętowane przez chrzest ${ }^{20}$.

W innym swym dziele 0 chrzcie Tertulian wprost nazywa chrzest Janowy chrztem pokuty ${ }^{21}$, dlatego sformułowanie pierwszy chrzest katechumenów należy uznać za symboliczne określenie tego właśnie chrztu. Warto podkreślić, że Kartagińczyk akcentuje naukę o jednym chrzcie ${ }^{22}$, dlatego omawiane sformułowanie jest parabolą, a nie informacją o faktycznym udzieleniu jakiegoś wcześniejszego chrztu. Autor w tym traktacie również używa obrazu chrztu jako pieczęci, kiedy pisze:

Jan bowiem, poprzednik Pana, nic innego nie czynił, jak tylko przygotował mu drogę. Podobnie i anioł chrztu toruje drogi przychodzącemu później Duchowi Świętemu. Usuwa najpierw grzechy przez wiarę oznaczoną pieczęcią Ojca i Syna i Ducha Świętego ${ }^{23}$.

\footnotetext{
20 Zob. L. Mateja, Wtajemniczenie w bezgrzeszność w „De paenitentia” Tertuliana, s. 39-40.

21 Tertullianus, De baptismo, 10, 5-7, s. 79-81 (Sources Chrétiennes 35), tłum. E. Stanula, s. 143-144 (Pisma Starochrześcijańskich Pisarzy 5).

22 Por. tamże, 12, 8, s. 84-85 (Sources Chrétiennes 35), tłum. E. Stanula, s. 146 (Pisma Starochrześcijańskich Pisarzy 5).

23 Tamże, 6, 1, 3-8, s. 75 (Sources Chrétiennes 35), tłum. E. Stanula, s. 139 (Pisma Starochrześcijańskich Pisarzy 5).
} 
W ostatnim zdaniu Tertulian podkreśla, że w trakcie przygotowania adepta do chrztu zostają mu najpierw usunięte grzechy przez wiarę, co należy powiązać z doświadczeniem usprawiedliwienia przez wiarę, o czym pisze św. Paweł (Rz 3, 21-24; Ga 2, 16). Następnie to doświadczenie jest przypieczętowane samym aktem chrztu. Ponadto w cytowanym fragmencie możemy wyróżnić trzy etapy wtajemniczenia chrześcijańskiego. Pierwszym jest nawrócenie, które symbolizuje chrzest Janowy i ten etap można nazwać prekatechumenatem. Drugim jest czas katechumenatu, którego celem było pogłębienie wiary w Jezusa Chrystusa, co owocowało w życiu inicjowanego doświadczeniem usprawiedliwienia przez wiarę. W ten sposób katechumen przygotowywał się do chrztu, który był pieczęcią potwierdzającą jego wolność od grzechu. Ostatnim trzecim etapem wtajemniczenia było posłuszeństwo Duchowi Świętemu (Rz 8, 14), które jak pokażemy później przygotowywało chrześcijanina do przyjęcia chrztu krwi, czyli męczeństwa za wiarę w Jezusa Chrystusa.

Kolejny raz Tertulian używa obrazu pieczęci na określenie chrztu, kiedy podkreśla konieczność udzielania go tym, którzy uwierzyli w Jezusa Chrystusa. Cały bowiem traktat 0 chrzcie, został napisany w celu odparcia herezji negującej konieczność chrztu i podkreślającej, że sama wiara wystarcza do zbawienia. Poglądy te głosiła pod koniec II wieku kobieta o imieniu Kwintylla z sekty kainickiej. Herezja ta jest świadectwem jak ogromną rolę w pierwotnym chrześcijaństwie przypisywano samej wierze. Dziś można obserwować drugi brzeg tej herezji, kiedy podkreśla się samo znaczenie aktu chrztu, marginalizując doświadczenie egzystencjalnej wiary. Zresztą te fałszywe poglądy występowały również w czasach Tertuliana, które obala w innym swoim dziele 0 pokucie ${ }^{24}$.

Kartagińczyk przeciwstawiając się poglądom Kwintylli, pisze:

Przed męką i zmartwychwstaniem Pana, sama wiara wystarczyła do zbawienia. Skoro jednak u wierzących wiara objęła Jego narodzenie, mękę i zmartwychwstanie, wówczas została wzbogacona również o tajemnicę, pieczęć chrztu, która stała się dla dawnej, nagiej wiary jakby szatą, nie może bowiem już istnieć bez prawa. Ustanowiono bowiem prawo chrztu i określono jego formę: „Idźcie, powiada,

24 Por. Tertullianus, De paenitentia, 6, 3-10, s. 164-166 (Sources Chrétiennes, 316), tłum. E. Stanula, s. 182-183 (Pisma Starochrześcijańskich Pisarzy 5), zob. L. Mateja, Wtajemniczenie w bezgrzeszność w „De paenitentia” Tertuliana, s. 41-42. 
nauczajcie narody, chrzcząc je w imię Ojca i Syna i Ducha Świętego" [Mt 28, 19]. Temu zaś prawu dodano to określenie: „Jeśli się kto nie odrodzi z wody i Ducha Świętego nie wejdzie do królestwa niebieskiego" [J 3, 3]. Ono właśnie zespoliło wiarę z koniecznością chrztu. I stąd wszyscy wierzący przyjmują chrzest ${ }^{25}$.

Tertulian w tych słowach ukazuje nauczanie Kościoła, które zawsze przebiega pośrodku przeciwstawnych herezji, akcentując konieczność zarówno wiary jak i chrztu, o czym wprost nauczał Jezus: „Kto uwierzy i przyjmie chrzest, będzie zbawiony” (Mk 16, 6). Kartagińczyk obok obrazu pieczęci używa jeszcze symboliki szaty w kontekście chrztu, a także podkreśla aspekt prawny udzielania chrztu wynikający wprost z Ewangelii.

Przytoczymy jeszcze jeden fragment $z$ innego pisma Tertuliana pt. Preskrypcja przeciw heretykom, gdzie autor używa obrazu pieczęci na określenie chrztu, kiedy pisze o wierze i nauczaniu Jana apostoła:

Zna on jednego Boga, Stwórcę wszechświata i Jezusa Chrystusa z dziewicy Maryi zrodzonego Syna, Boga Stwórcy i w ciała zmartwychwstanie. Łączy w jedną całość Prawo i Proroków razem z Ewangeliami i Listami Apostolskimi; stąd czerpie wiarę, którą woda pieczętuje, odziewa się Duchem Świętym, żywi Eucharystią, zachęca do męczeństwa i nie przyjmuje nikogo, kto byłby w sprzeczności z taką właśnie nauką ${ }^{26}$.

Kartagińczyk ukazuje źródło wiary chrześcijan, którym jest Stary i Nowy Testament. Egzystencjalne wyznanie wiary czerpanej z tego źródła, było pieczętowane wodą chrztu świętego. Ochrzczony mógł się karmić Eucharystią, a dzięki temu był gotowy do przyjęcia męczeństwa za wiarę w Jezusa Chrystusa. Na koniec Tertulian podkreśla, że nie przyjmowano do wspólnoty Kościoła nikogo, kto żyłby w sprzeczności z tak sprecyzowanymi kanonami nauki chrześcijańskiej, co jest świadectwem procedury wtajemniczania i weryfikacji egzystencjalnej wiary w starożytnym Kościele.

25 Tertullianus, De baptismo, 13, 2-3, s. 85-86 (Sources Chrétiennes, 35), tłum. E. Stanula, s. 147 (Pisma Starochrześcijańskich Pisarzy, 5).

26 Tertullianus, De praescriptione 36, 5, 16-22, Paris 1957, s. 138-139 (Sources Chrétiennes, 46), przekł. pol.: Tertulian, Preskrypcja przeciw heretykom, w: Tertulian, Wybór pism, tłum. E. Stanula, Warszawa 1970, s. 71 (Pisma Starochrześcijańskich Pisarzy, 5). 
Warto jeszcze spojrzeć na inny tekst Tertuliana, w którym podejmuje temat chrztu krwi, rozumiany jako męczeństwo za wiarę w Jezusa. W traktacie 0 chrzcie pisze w następujący sposób:

Jest u nas jeszcze drugi chrzest, który także jest jeden i ten sam, mianowicie chrzest krwi. O nim mówił Pan, gdy był już ochrzczony: „mam być chrztem ochrzczony”. Przyszedł bowiem jak Jan napisał: „przez wodę i krew". Wodą bowiem został ochrzczony, a przez krew uwielbiony. W ten sposób przez wodę nas wzywa, a przez krew czyni nas wybranymi. Obydwa te chrzty wypłynęły z rany przeszytego boku, ponieważ ci, którzy uwierzyli w Jego krew, zostają wodą obmyci, ci którzy wodą się obmyli powinni się też i krwią poić. To jest właśnie chrzest, który zastępuje i nie przyjęte obmycie i utracone przywraca ${ }^{27}$.

W przedostatnim zdaniu autor zdaje się wiązać chrzest krwi z komunią świętą, konkretnie z Krwią Pańską, którą powinni poić się ci, którzy woda się obmyli. Można sądzić, że zdaniem Tertuliana w chrzcie krwi uczestniczą już ci, którzy spożywają krew Pańską na Eucharystii. Choć chrześcijanie wielokrotnie w ten sposób zanurzają się w tak rozumianym chrzcie krwi, to jednak jest to ciągle ten sam jeden chrzest, jak to podkreślił na początku cytowanego wyżej fragmentu. Eucharystia jest bowiem uobecnieniem męki, śmierci i zmartwychwstania Jezusa, czyli jest jednym wydarzeniem, podobnie jak wielokrotne spożywanie Krwi Pańskiej.

Natomiast w ostatnim cytowanym zdaniu powyższego fragmentu, Kartagińczyk łączy doświadczenie chrztu krwi rozumianego jako męczeństwo z chrztem z wody, kiedy pisze, że chrzest krwi zastępuje nie przyjęte obmycie. W ten sposób nawiązuje do praktyki starożytnego Kościoła, która uznawała, że katechumen osiągnął zbawienie, kiedy oddał życie za wiarę w Jezusa. Ten bowiem, który nie przyjął chrztu w imię Chrystusa, poprzez swe męczeństwo zanurzał się w Krwi Pańskiej, a wtedy doświadczał owoców obmycia z wody. Natomiast, kiedy Tertulian pisze o chrzcie krwi, który utracone obmycie przywraca, myśli o innej zasadzie, która uznawała, że kiedy chrześcijanin po chrzcie popełnił grzech wykluczający go ze wspólnoty Eucharystycznej, a w czasie trwania pokuty

27 Tertullianus, De baptismo, 16, 1-2, s. 89 (Sources Chrétiennes, 35), tłum. E. Stanula, s. 149 (Pisma Starochrześcijańskich Pisarzy, 5). 
oddał życie za Chrystusa, wtedy chrzest krwi przywracał mu pewność zbawienia wynikającą z chrztu z wody.

Porównując ze sobą dwa wyszczególnione wyżej podejścia do chrztu krwi, jako spożywanie Krwi Pańskiej na Eucharystii i jako przyjęcie męczeństwa za wiarę w Chrystusa, można wyciągnąć wniosek, że Tertulian rozumiał przyjmowanie w komunii świętej Krwi Pańskiej jako przygotowanie do męczeństwa za wiarę. W podobny sposób wypowiadał się bowiem w utworze Preskrypcja przeciw heretykom, w cytowanym wcześniej fragmencie, kiedy wyliczając etapy wtajemniczenia chrześcijańskiego po chrzcie, pisał: „odziewa się Duchem Świętym, żywi Eucharystią, zachęca do męczeństwa"28. Tak więc Eucharystia, a dokładnie Krew Pańska, zdaniem Tertuliana jest napojem przygotowującym chrześcijanina do oddania życia za wiarę w Jezusa Chrystusa.

Podsumowując należy stwierdzić, że nowym aspektem symboliki chrztu jako pieczęci w pismach Tertuliana w stosunku do świadectw autora Pasterza Hermasa i Klemensa Aleksandryjskiego, jest ukazanie szerszej perspektywy tego wydarzenia. Kartagińczyk bowiem akcentuje konieczność wzrostu egzystencjalnej wiary w Jezusa przed chrztem, dzięki czemu inicjowany doświadczał usprawiedliwienia z grzechów, które dziś nazwalibyśmy grzechami personalnymi. Chrzest pieczętował to doświadczenie, a zarazem udzielał łaski usprawiedliwienia z grzechu natury, czyli grzechu pierworodnego. Ponadto autor ukazuje dalszą perspektywę wzrostu egzystencjalnej wiary przez posłuszeństwo Duchowi Świętemu i karmienie się Eucharystią. W ten sposób chrześcijanin przygotowywał się do męczeństwa za wiarę w Jezusa Chrystusa. Przywołane teksty Tertuliana są świadectwem, że w starożytnym Kościele był położony nacisk na nieustanny rozwój duchowy. Najpierw inicjowany był wezwany do nawrócenia, czyli w wymiarze symbolicznym do przeżycia chrztu Janowego. Następnie rozpoczynał przygotowanie do przyjęcia chrztu w imię Ojca i Syna, i Ducha Świętego w ramach katechumenatu. Po przyjęciu pieczęci chrztu, jego rozwój duchowy się nie kończył, bowiem był teraz wezwany do przygotowania się do doświadczenia chrztu krwi,

${ }_{28}$ Tertullianus, De praescriptione 36, 20-21, s. 138 (Sources Chrétiennes, 46), tłum. E. Stanula, s. 71 (Pisma Starochrześcijańskich Pisarzy, 5). 
czyli męczeństwa za wiarę w Jezusa Chrystusa. Nieodzownym elementem przygotowania do tego „drugiego chrztu” było przyjmowanie Krwi Pańskiej pod postacią wina.

\section{Podsumowanie}

Podsumowując przywołane świadectwa dotyczące rozumienia chrztu w starożytnej tradycji żydowskiej i chrześcijańskiej, należy podkreślić, że każde zanurzenie rozumiano wtedy, jako obmycie kończące pewien etap wtajemniczenia. Zasada, która wtedy obowiązywała we wspólnocie z Qumran, a także wśród Żydów przyjmujących chrzest Janowy, a następnie w pierwotnym Kościele, była taka sama. Najpierw należało zmienić życie, aby później przyjąć chrzest, który był niejako pieczęcią potwierdzającą tę zmianę. Z punktu widzenia inicjacyjnego należy jednak podkreślić, że zmiana dotycząca chrztu Janowego miała na celu dostosowanie życia Żydów do przestrzegania Prawa Bożego objawionego w Starym Testamencie. Natomiast adepci przygotowujący się do chrztu w Kościele, byli zobowiązani do przestrzegania przykazań Jezusa, które syntetycznie ukazał w Kazaniu na Górze. Nowym zaś prawem, które obowiązywało już ochrzczonych było przykazanie miłości wzajemnej (J 15, 10-13).

Ponadto wykazaliśmy, że w II i III wieku w różnych środowiskach kościelnych, czyli w Rzymie, Aleksandrii i Kartaginie rozumiano chrzest jako pieczęć, potwierdzającą egzystencjalne wyznanie wiary w Jezusa jako Syna Bożego, czyli Boga. Po przyjęciu tak rozumianego chrztu, rozpoczynał się kolejny etap rozwoju egzystencjalnej wiary, w ramach przygotowania do chrztu krwi, czyli męczeństwa za wiarę w Jezusa Chrystusa. Chrzest Janowy, czyli chrzest nawrócenia i chrzest krwi były rozumiane przez chrześcijan symbolicznie. Te dwa doświadczenia stanowiły niejako ramę dla jedynego chrztu udzielanego w imię Ojca i Syna, i Ducha Świętego, który był wydarzeniem centralnym. Chrzest, który udzielał Jan Chrzciciel pieczętował nawrócenie. Chrzest w imię Ojca i Syna, i Ducha Świętego był pieczęcią duchowego ożywienia. Natomiast chrzest krwi dotyczył dobrowolnego przyjęcia męczeństwa, które pieczętowało fakt całkowitego zjednoczenia się przez wiarę z Jezusem. 


\section{Summary}

\section{Chrzest jako misterium pieczęci w tradycji pierwszych trzech wieków}

Artykuł ukazuje, w jaki sposób w pierwszych trzech wiekach rozumiano chrzest jako misterium pieczęci. Ten aspekt chrztu był już podkreślany we wspólnocie z Qumran, a także w doświadczeniu chrztu Jana Chrzciciela, o czym w I wieku pisał Józef Flawiusz. Ojcowie Kościoła w II i III wieku używają wprost sformułowania pieczęć chrztu. Autor Pasterza Hermasa reprezentujący środowisko Rzymskie oraz Klemens Aleksandryjski uważali, że chrzest w imię Ojca i Syna, i Ducha Świętego pieczętował egzystencjalne wyznanie wiary w Jezusa jako Syna Bożego. Natomiast Tertulian z Kartaginy ukazał szerzej proces wzrostu egzystencjalnej wiary w ramach procedury inicjacji przedchrzcielnej, a także jej dalszy rozwój przygotowujący chrześcijan do przyjęcia chrztu krwi, czyli męczeństwa za wiarę w Jezusa. Chrzest Janowy, czyli chrzest nawrócenia i chrzest krwi były rozumiane przez chrześcijan symbolicznie i stanowily niejako ramę dla jedynego chrztu, przez nich przyjmowanego.

Słowa kluczowe: wiara, chrzest, inicjacja, katechumenat, Kościół

The baptism as the mystery of the seal in the tradition of the first three centuries

The article shows how the baptism was understood in the Church of the first three centuries as the mystery of the seal. This aspect of the baptism was emphasized by Qumran community. It was also evident in the experience of the baptism of John the Baptist, what was described in the first century by Flavius Josephus. The Fathers of the Church in the 2nd and 3rd century were using the phrase seal of baptism directly. The author of The Shepherd of Hermas, who represented Roman community and Clement of Aleksandria deemed that the baptism in the name of the Father, and of the Son, and of the Holy Spirit set the seal on the existential confession of faith in Jesus as the Son of God. Tertullian from Carthage described more broadly the process of increase in the existential faith during the pre-baptismal initiation and its further development preparing for the baptism of blood, that is for the martyrdom due to the faith in Jesus. Christians understood the baptism of John the Baptist, that is the baptism of conversion as well as the baptism of blood symbolically, as a frame for the only baptism which they received.

Keywords: faith, baptism, initiation, catechumenate, Church 


\section{Bibliografia}

Clemens Alexandrinus, Stromata, Paris 1951 (Sources Chrétiennes, 30), przekł. pol.: Klemens Aleksandryjski, Kobierce zapisków filozoficznych dotyczacych prawdziwej wiedzy, t. 1, tłum. J. Niemirska-Pliszczyńska, Warszawa 1994.

Clemens Alexandrinus, Stromata, Paris 1980 (Sources Chrétiennes, 278), przekł. pol.: Klemens Aleksandryjski, Kobierce zapisków filozoficznych dotyczacych prawdziwej wiedzy, t. 2, tłum. J. Niemirska-Pliszczyńska, Warszawa 1994.

Ferguson E., Baptism in the Early Church. History, Theology, and Liturgy in the First Five Centuries, Grand Rapids 2009.

Folkemer L. D., A study of the Catechumenate, „Church History” 15 (1946), s. 286-307.

Górka B., Struktura inicjacji w tzw. dłuższym zakończeniu Ewangelii Marka (16,9-20), w: tegoż autora, Kerygma i Ekklesia w kontekście inicjacji, Kraków 2016.

Haręzga S., Jezus i Jego uczniowie. Model chrześcijańskiej formacji w Ewangelii według św. Marka, Lublin 2006.

Hermas, Pastor, Paris 1968 (Sources Chrétiennes 53), przekł. pol.: Hermas, Pasterz, w: Pierwsi świadkowie. Pisma Ojców Apostolskich, wyd. 2, tłum A. Świderkówna, Kraków 1998 (Biblioteka Ojców Kościoła, 10).

Johnson M. E., The Rites od Christian Initiation. Their Evolution and Interpretation, Collegeville 2007.

JózefFlawiusz,DawnedziejeIzraela,18,117,tłum.Z.Kubiak,J.Radożycki,Warszawa1979.

Katechumenat $i$ inicjacja chrześcijańska w Kościele starożytnym, red. F. Drączkowski, J. Pałucki, P. Szczur, M. Szram, M. Wysocki, M. Ziółkowska, Lublin 2011.

Łucarz S., Disciplina arcani w „Kobiercach” Klemensa Aleksandryjskiego, w: Disciplina arcani w chrześcijaństwie, red. W. Gajewski, B. Górka, Kraków 2015, s. 75-91.

Łucarz S., Inicjacja w ujęciu Klemensa Aleksandryjskiego, w: Kondycja chrześcijaństwa dzisiaj a inicjacja chrześcijaństwa starożytności, Gdańsk 2005), s. 105-115 (Christianitas Antiqua. Commentationes, 1).

Malina A., Ewangelia według św. Marka (1, 1- 8, 26), cz. 1, Częstochowa 2013.

Mateja L., Wtajemniczenie w bezgrzeszność w „De paenitentia” Tertuliana, w: Grzech $i$ dyscyplina w kościele antycznym, red. W. Gajewski, Gdańsk 2015, s. 39-50 (Christianitas Antiqua,7).

Mokrzycki B., Droga chrześcijańskiego wtajemniczenia, Warszawa 1983.

Rękopisy znad Morza Martwego. Qumran - Wadi Murabba'at - Masada, przekł. pol. P. Muchowski, Kraków 1996.

Tertullianus, De baptismo, Paris 1952 (Sources Chrétiennes, 35), przekł. pol.: Tertulian, O chrzcie, w: Tertulian, Wybór pism, tłum. E. Stanula, Warszawa 1970 (PSP, 5).

Tertullianus, De paenitentia, Paris 1984 (Sources Chrétiennes, 316), przekł. pol.: Tertulian, O pokucie, w: Tertulian, Wybór pism, tłum. E. Stanula Warszawa 1970 (PSP, 5).

Tertullianus, De praescriptione, Paris 1957 (Sources Chrétiennes, 46), przekł. pol.: Tertulian, Preskrypcja przeciw heretykom, w: Tertulian, Wybór pism, tłum. E. Stanula, Warszawa 1970 (PSP, 5). 